\title{
Reality of Strategic Planning Practice from the Perspective of Education Faculty Members
}

\author{
Mayada M. Al Basel ${ }^{1, *} \&$ Rania W. Osman ${ }^{1}$ \\ ${ }^{1}$ Fundamentals of Education, Faculty of Education, Damietta University, Egypt \\ *Correspondence: Fundamentals of Education, Faculty of Education, Damietta University, Egypt. E-mail: \\ dr_raniawasfy@yahoo.com
}

Received: February 1, 2020

Accepted: March 15, 2020 Online Published: April 20, 2020

doi:10.5430/wje.v10n2p127

URL: https://doi.org/10.5430/wje.v10n2p127

\begin{abstract}
The present study aimed to identify the reality of strategic planning practice by the leaders of the Faculty of Education, Damietta University from the perspective of faculty members. Therefore, it adopted the descriptive approach based on a survey of (63) faculty members. It applied a five-domain questionnaire. Results revealed the weak practice of strategic planning from the perspective of the participants. "Future challenges" domain was ranked first and rated "high" with a weighted average of (3.62) and a percentage of (72.38\%). "Preparation for strategic planning" domain was ranked second and rated "moderate" with a weighted average of (3.14) and a percentage of $(62.74 \%)$. The $3^{\text {rd }}, 4^{\text {th }}$, and $5^{\text {th }}$ domains regarding "quadratic strategic analysis, implementation of the strategic plan, and evaluation and strategic oversight" were ranked low. Their weighted averages were rated $(2.28-2.50)$ with a percentage of (49.91\%-64.24\%).
\end{abstract}

Keywords: strategic planning, academic leaders, faculty of education, Damietta University

\section{Introduction}

University education and scientific research are the basis for state development. They can not be promoted but by setting policies, future trends, and strategic plans. Higher education institutions encounter various challenges internally and externally, such as globalization, communication revolution, and knowledge revolution. They also have to respond to emerging challenges, such as lack of financial support, technological advances, demographic changes, and old academic programs. Therefore, many universities have turned to strategic planning to adapt to a rapidly changing environment (Gomaa, 2012, p.262).

In the $21^{\text {st }}$ century, higher education institutions play various roles. They not only educate and train students, but they also come up with new ideas and knowledge of contemporary short-term issues and complex long-term problems through strategic objectives. Higher education seeks to achieve five important aspects, namely the democratization of knowledge, market competition and finance, research techniques, global mobility, and integration with industry. Therefore, higher education institutions should adopt strategic planning (Sart, 2014, p.34).

Strategic planning is vital for the success of colleges and universities. Michael and Liz (2009) argue that strategic planning enables colleges and universities to analyze the present and predict the future to maintain competitive advantages. They are prepared for new trends, technologies, and evolving requirements. Therefore, they develop an appropriate planning method that includes effective analysis, prioritizing objectives, goal setting, and implementation. Such planning merges long-term planning model and an environmental survey model to establish effective strategic planning.

Strategic planning in university education is an administrative process concerned with the achievement of long-term and medium-term objectives and the utilization of the available resources in accordance with particular legislation, activities, and programs that help accomplish the desired objectives, taking into account the internal and external environment (Al-Shehri and Ibrahim, 2018, p. 7). According to Obeidat (2011), strategic planning is the process by which the university resources are coordinated with their long-term opportunities. It is "a collaborate 'action road map' structured to guide the institution's ongoing process that questions the changes in the environment, initiates new learning criteria, and adjusts the guidance as new information becomes available" (Gordon and Fischer, 2015, 
p.6).

It goes through several steps. Gordon and Fischer (2015) define the basic steps, as follows:

Formulation of the future trend: Mission and vision of the institution.

- Implementation: It requires actions with identified responsibilities as well as resource allocations related to strategic priorities.

- Evaluation: It is based on measurable and time-limited objectives.

Chang (2006) defines three primary stages of strategic planning.

Sector analysis: It reviews how the system functions (internal dynamics) to fulfill people's needs and examines various driving forces of the education system and external conditions (the surrounding environment), e.g. macroeconomic and socio-demographic situations and developments.

Policy design: It is done based on multiple dimensions, e.g. participation, quality, internal efficiency, external efficacy, governance, decentralization, and resource management.

Action planning: It is based on formulating action plans to transform the operational terms into policy orientations to be developed by the educational authorities within a given time frame.

Dhaher (2016, pp.18-19) defines the stages of strategic planning, as follows:

- Defining the institution's mission: It defines the institution's goals and future orientation.

- SWOT Analysis: It highlights opportunities, threats, strengths, and weaknesses.

- Setting strategic objectives: It describes the desired results according to the efforts of the institution.

- Development of the strategic options: It develops the orientation of the institution to achieve its goals and mission.

- Identify the best strategic option: It is the consequence of sequential process that starts with evaluating strategic alternatives and chooses the best.

- Implementation of the strategic option: It is an intermediate link between formulation and strategy control, on one hand, and the aspects of current and future life, on the other.

Hassanien (2017) believes that strategic planning in higher education institutions goes through the following stages:

- Nominate the Steering Committee for Strategic Planning: It includes experts in strategic planning and qualified members from different departments, one external stakeholder, at least, and a member of the financial administration in the Faculty.

- Drafting mission and vision: It is done based on the philosophy of the university and the faculty after consultation with the different departments, as well as internal and external stakeholders.

- SWOT analysis: It defines strengths, weaknesses, opportunities, and threats. It also evaluates the difference between the current situation and the desired future according to the vision.

- Benchmarking with a higher education institution in the light of performance indicators.

Strategic planning is important because it achieves many benefits. Obeidat (2011, p.5) claims that strategic planning:

- Defines the problems or obstacles to the achievement of objectives.

- Motivates leaders or higher administration to draft a common future vision and to maximize its role in the technical aspects.

- Instills teamwork and deepens coordination between the different administrative levels.

- Unifies the value system based on total quality, transparency, justice, accountability, innovation, creativity, controlled institutional performance, and job satisfaction.

- Employs strengths and opportunities and reduces threats and weaknesses to achieve the strategic vision.

- Provides qualitative and quantitative performance indicators to follow up the implementation of plans and achievement of objectives within a timeframe.

- Qualifies and trains human cadres at the different administrative and technical levels.

- Invests the financial resources and controls and guides expenses to implement future plans and programs.

By adopting strategic planning, the departments of the faculty, as educational intitutions, aims to achieve various 
objectives (Dahawy and Almelegy, 2011, pp.112-113), such as:

- Studying the current situation of the institution by analyzing the internal and external environments, promoting strengths, and addressing weaknesses.

- Administrative development of the faculty to challenge future changes and handle obstacles.

- Setting strategies that resolves educational problems.

- Expecting and adapting to changes in the surronding environment.

- Ultimate utilization of the available resources.

- Highlighting the faculty's personality to the stakeholders.

- Increasing communication and interaction with the community to raise community awareness.

- Developing and improving decision-making to improve the work environment.

Damietta University is a higher education institution in Egypt. It started with establishing classes for some faculties of Mansoura University in Damietta. Later, the decrees were issued to establish faculties in Damietta campus according to the regulations of the corresponding faculties of Mansoura University. The Faculty of Education was established in 1976-1977 according to the ministerial decree no. 1142 of 1977. In 2007, the presidential decree No (276) was issued to establish the campus of Mansoura University in Damietta. In July 2012, the presidential decree No (19) of 2012 was issued to establish Damietta University to be based in New Damietta (Damietta University, 2014/2015).

The Faculty of Education, Damietta University aims to qualify educational leaders and teachers. It has a vision "to strive to deliver quality and excellence and to have a prominent place on the map of higher education by providing a distinct environment for teaching, learning, conducting educational research, and serving the university and the community to obtain accreditation" (Faculty of Education, 2008, p. 15). Therefore, it employs strategic planning as a contemporary development trend that has been applied recently. Institutions should adopt and apply this approach to achieve its objectives (Badrakhan, 2016).

The problem of the present study was defined in highlighting the reality of strategic planning practice by the leaders of the Faculty of Education, Damietta University from the perspective of faculty members. It raises the following question: To what extent do the leaders of the Faculty of Education, Damietta University practice strategic planning from the perspective of faculty members?

\subsection{Objectives}

The study aims to identify the extent of practicing strategic planning by the leaders of the Faculty of Education, Damietta University as an important issue in the educational literature. It also examines applying the scientific steps of strategic planning by the administration of the Faculty as an educational institution in Egypt from the perspective of the faculty members.

\subsection{Significance}

The theoretical significance of the study is based on its scientific and applied significance of the concept of strategic planning in universities as a modern trend that maximizes the outcomes of university education in Egypt and promotes teacher preparation. It is one of the few studies that tackle strategic planning at the Faculties of Education in the Arab World, in general, and in Egypt, in particular. It is significant because identifying the reality of strategic planning practice is an evaluation of the strategic plans adopted by the faculty to promote strengths and handle weaknesses. Accordingly, it helps the leaders of the Faculty of Education, Damietta University achieve the desired change by promoting its ability to resolve problems, support teacher participation, allocate resources and facilities effectievely, achieve long-term environmental interaction, and support the competitive position of the faculty.

\subsection{Limitations}

Human limits: The academic cadres of deans, deputies and heads of departments of different ranks (professorassistant professor- lecturer).

Spatial limits: The Faculty of Education, Damietta University

Temporal limits: The second semester of 2018-2019

Objective limits: Investigating the reality of strategic planning practice by the leaders of the Faculty of Education, Damietta University via five domains, namely preparing for strategic planning, defining future trends, quadratic 
strategic analysis, implementation of the strategic plan, and evaluation and strategic oversight.

\subsection{Definition of Terms}

The authors define strategic planning as an organized process done by the leaders of thefaculty to choose the best solutions of achieving objectives and prioritization in the light of the available human and material facilities. It goes through the following steps: Preparing for strategic planning, defining future trends, quadratic strategic analysis, implementation of the strategic plan, and evaluation and strategic oversight.

\subsection{Literature Review}

Several studies addressed strategic planning in higher education. For example, Machado, Taylor, Farhangmehr, and Wilkinson (2005) conducted a national analytical study on strategic planning in the Portuguese higher education. The study covered the leaders of (61) private and public higher education institutions in terms of knowledge and practice of strategic planning. It applied a questionnaire to find out whether the institutions plan or not, the components of planning, the institutional benefits and relevant problems, as well as personal benefits. Results revealed the need to a comprehensive strategic plan to guide Portugal to succeed in the future. The common models in higher education institutions lack professionalism and hinder strategic development. Thus, the resources are not used effectievely and institutional innovation is not promoted.

Sullivan and Richardson (2011) aimed to provide the leaders of the education institutions in the United States of America with an integrated model to support strategic planning initiatives. The study provided a model to exceed traditional strategic planning by aligning strategic planning initiatives with higher education practices, staff performance, and evaluation of results. Thus, it could help leaders participating in the efforts of strategic planning achieve objectives and obtain desired results.

Sart (2014) aimed at analyzing the strategic plans of Istanbul's public and private universities to understand their dynamics in depth. The results showed that most universities have a misconception regarding the model and strategic plan. Neither private nor public universities have sufficient knowledge about the issue.

Lillis and Lynch (2014) aimed to explore the experiences of 21 universities and technology institutes in Ireland from 2000 to 2010 . The study clarified whether the strategic planning models used in the past decade would be able to meet the challenges of the unprecedented economic circumstances and the new national strategy for higher education. It utilized qualitative methods, including analysis of the documents of strategic planning and interviewing senior directors of strategic planning. Results revealed a major deficiency in strategic planning in terms of institutional diversity, performace-related finance, and participation of external stakeholders.

Orians and Bergerson (2014) described strategic planning initiated by the Student Affairs Department at Mountain College, Colorado, USA. The study analyzed several issues related to institutional identity, development of the strategic planning initiative, engagement of the faculty members and staff, and changing landscape of higher education.

Gordon and Fischer (2015) aimed to analyze the strategic plans of eight universities. The study examined whether strategic plans meet the basic concepts of planning. Results revealed that strategic planning is not employed in higher education for institutional improvement. Moreover, lack of commitment to the principles of strategic planning is because strategic plaaning focuses on public relations or media of accreditation agencies that require documenting strategic planning. University leaders do not adopt the principles of strategic planning to promote continuous improvement due to the lack of an organized infrastructure to follow up the real and planned results to define corrective actions.

Han and Zhong (2015) aimed to develop strategic maps as tools for transformational management in Chinese universities. The study analyzed 15 strategic maps of universities, using Tsinghua University as a model to illustrate how the university's strategic plan can be turned into a strategic map. Results concluded a model of the effective use of the strategic maps of universities. It made suggestions of the consequences of strategic maps to turn internal governance and effective strategic planning and administration.

Badrakhan (2016) aimed to identify the reality of strategic planning in the public and private Jordanian universities in the light of total quality standards. It developed and applied a questionnaire to (610) academic cadres to measure strategic planning. Results revealed that the level of strategic planning in the light of total quality standards was high.

Dhaher (2016) aimed to highlight the degree of strategic planning practice and relationship to the development of e-learning at the Palestinian universities (Al-Quds Open University- a case study). The study adopted the descriptive approach. It applied a questionnaire to a sample of (152) senior leaders at the university. Results revealed that the 
practice of strategic planning at Al-Quds Open University was high.

Tess (2018) aimed to reveal the effectiveness of strategic planning practices in Australian universities. The study illustrated that strategic planning has been a controversial in Australian universities since 30 years. The universities could replace traditional academic planning with strategic planning.

Al-Shehri and Ibrahim (2018) aimed to identify the organizational obstacles to strategic planning at Prince Sattam bin Abdulaziz University. The study adopted the descriptive approach and applied a questionnaire to (357) faculty members and staff. It concluded that the most significant obstacles included the lack of a system of incentives to the distinguished departments in applying the university strategic plan, the shortage of strategic planning manuals, and the gap between the different levels of administration in developing and applying the strategic plan.

\subsection{Commentary}

- Many international studies were interested in investigating strategic planning in higher education. For example, some studies, such as Gordon and Fischer (2015) and Tess (2018) evaluated strategic planning and highlighted its effectiveness. Other studies, e.g. Al-Shehri and Ibrahim (2018) and Machado et al. (2005), highlighted the obstacles to strategic planning in university education. Some studies, including Orians and Bergerson 92014) proposed models for the development of strategic planning process. Furthermore, some studies, e.g. Lillis and Lynch (2014), addressed the historical development of strategic planning in universities nationally.

- Most of the studies agreed on the necessity of practicing strategic planning as a means to help universities improve management and achieve goals to face contemporary challenges.

- The study benefitied from the literature in developing the appropriate method and tool and discussing results. However, it differs because most of the studies addressed strategic planning in highrt education in different countries, such as Saudi Arabia, Jordan, Palastine, Australia, China, Ireland, Turkey, the United States, and Portugal. The present study addressed strategic planning practice at the Faculty of Education, Damietta University.

\section{Methodology}

This section covers the method, objective of the field study, tool, sampling, statistical processing, as well as results and discussion.

\subsection{Method}

This study adopted the descriptive approach using quantitative and qualitative methods to collect and analyze data. It applied a questionnaire was used to a sample of the faculty members at the Faculty of Education, Damietta University.

\subsection{Objective of the Field Study}

The field study aimed to identify strategic planning practice among the leaders of the Faculty of Education, Damietta University from the perspective of the faculty members.

\subsection{Developing the Tool}

To achieve the objective of the field study, a questionnaire was developed by reviewing the relevant literature that highlights the subject and defines the domains of the questionnaire. It was designed based on the Likert Scale. The participants responded to a five-point scale, as follows: Very highly (5), high (4)- moderate (3), poor (2), and very poor (1).

The primary form included 45 items distributed to five domains, representing the strategic planning stages. It was presented to (12) reviewers of the specialized professors of the Faculty of Education to estimate the vaidity, clarity, wording, and suggestions of each item. Some items were modified, five items were eliminated for repetition. Thus, the final form comprised 40 items.

\subsection{Validity and Reliability}

The reliability of the questionnaire was calculated using Cronbach's Alpha. It estimated (0.86-0.92) for the domains and $(0.96)$ for the tool. They are high results indicating the reliability of the tool.

For validity, the final form of the questionnaire was submitted to a group of professors at the Faculty of Education. They reported that the tool and domains are appropriate for application. Internal consistency was calculated by estimating the correlation between the items and the domain. The correlation coefficients estimated (0.47-0.95), which are statistically significant at the level of $(0.01)$. consequently, the items are valid. 


\subsection{Population and Sampling}

The population covered the faculty members at the Faculty of Education, Damietta University. In sampling, the authors took into account the three academic ranks (professor- assistant professor- lecturer) that may or may not hold leadership positions, as shown in table 1.

Table 1. Population

\begin{tabular}{lllll}
\hline \multirow{2}{*}{ Faculty members } & Professor & Assistant professor & Lecturer & Total \\
\cline { 2 - 5 } & 22 & 24 & 31 & 77 \\
\hline
\end{tabular}

The questionnaires were distributed to a andomly selected sample of (70) faculty members. The authors received (67) questionnaires, (4) of which were not valid for statistical analysis because they were incomplete. Therefore, the sample that was statistically analyzed comprised (63) faculty members.

\subsection{Statistical Processing}

To analyze the data of the study, the authors adopted some statistical methods that are consistent with the nature of the study and variables using SPSS. The study utilized Cronbach's Alpha Coefficient, Pearson Correlation Coefficient, frequency, percentages, relative weight, standard deviation, and arithmetic mean.

\section{Results and Discussion}

\subsection{Results of the Responses to the Items of the First Domain}

Table 2. Frequencies, Arithmetic Means, Standard Deviations, and Percentages of the Participants' Responses to the Items of the First Domain "Preparing for Strategic Planning"

\begin{tabular}{|c|c|c|c|c|c|c|c|c|c|c|}
\hline \multirow[b]{2}{*}{ Items } & \multicolumn{5}{|c|}{ Response } & \multirow[b]{2}{*}{ Mean } & \multirow[b]{2}{*}{ SD } & \multirow{2}{*}{$\begin{array}{l}\text { Percentage } \\
\quad(\%)\end{array}$} & \multirow[b]{2}{*}{ Level } & \multirow[b]{2}{*}{ Ranking } \\
\hline & $\begin{array}{l}\text { Very } \\
\text { high }\end{array}$ & High & Moderate & Poor & Very poor & & & & & \\
\hline $\begin{array}{l}\text { Build trust supporting strategic planning at the } \\
\text { faculty }\end{array}$ & 8 & 2 & 42 & 8 & 3 & 3.06 & 0.93 & 61.27 & Moderate & 6 \\
\hline $\begin{array}{l}\text { Motivate the departments to have strategic } \\
\text { planning }\end{array}$ & 5 & 13 & 39 & 3 & 3 & 3.22 & 0.85 & 64.44 & Moderate & 3 \\
\hline $\begin{array}{l}\text { Develop the administrative leaders supporting } \\
\text { strategic planning }\end{array}$ & 8 & 8 & 30 & 16 & 1 & 3.10 & 0.98 & 61.90 & Moderate & 4 \\
\hline Hold meetings to discuss strategic planning & 11 & 15 & 26 & 7 & 4 & 3.35 & 1.09 & 66.98 & Moderate & 2 \\
\hline $\begin{array}{l}\text { Appoint a facilitator to lead the team of strategic } \\
\text { planning }\end{array}$ & 11 & 15 & 28 & 7 & 2 & 3.41 & 1.01 & 68.25 & High & 1 \\
\hline Employ experts of strategic planning & 8 & 10 & 13 & 28 & 4 & 2.84 & 1.17 & 56.83 & Moderate & 8 \\
\hline Formulate a team of strategic planning & 7 & 17 & 10 & 28 & 1 & 3.02 & 1.11 & 60.32 & Moderate & 7 \\
\hline Train the team of strategic planning & 11 & 7 & 22 & 23 & - & 3.10 & 1.09 & 61.90 & Moderate & 5 \\
\hline Preparing for Strategic Planning & & & & & & 3.14 & & 62.74 & Moderate & \\
\hline
\end{tabular}

Table 2 illustrates the responses to the items of the first domain concerning "preparing for strategic planning". Item (5) was rated high with a weighted average of (3.41) and a percentage of $(68.25 \%)$. Items $(1,2,3,4,6$, 7, and 8$)$ were rated moderate with weighted averages of (2.84-3.35) and percentages of (56.83\%-66.68\%).

The responses to the first domain of "preparing for strategic planning" were rated moderate with a weighted average of (3.14) and a percentage of (62.74\%). This finding is obtained because:

- Faculty leaders are aware of strategic planning as a must to develop a future perspective and necessary procedures.

- Leaders believe in the merit of strategic planning as an effective way to face the challenges encountered by the university education systems and keep pace with the changes in these challenges. Administrative leaders tend to strategic planning at the time of crisis.

- Leaders are committed to pursuing strategic planning in response to the strategy of higher education development 
(2015-2030) to meet Egypt's Vision 2030.

- Leaders seek to provide organizational culture that covers clear values and behavioral traditions to help the faculty members and the staff recognize the mission and behaviors.

- University leaders believe in the importance of training in disseminating awareness and introducing development methods to the participants. Therefore, the organizational structure of Damietta University includes the Faculty Development Center, which offers training and professional development programs to all levels of administration and meets their requirements. It offers a program of strategic planning.

- The organizational structure of the faculty includes a unit of quality assurance.

This finding agrees with Badrakhan (2016), revealing that governance and university administration are ranked first in terms of planning.

Nevertheless, the leaders encounter some obstacles to playing their role in strategic planning effectively. For example,

- The responsibilities related to planning are unclear. There is a misconception that strategic planning is the responsibility of a planning body and not the responsibility of the administration at various levels.

- The leaders perform various administrative tasks. Therefore, the time allocated to strategic planning is affected because the leaders devote time to short-term problems and routine.

- Many organizational obstacles related to the lack of human and technological competencies, weak organizational structure, and old legislation are encountered.

- Lack of compatibility between planning tasks and the individual skills of the leaders: Planning requires thinking at the level of the faculty and the relations between the faculty, as an institution, and the factors affecting them in the work environment. This incompatibility results in drawbacks, such as paying attention to operational issues only, inability to fulfil tasks, and interest in emergencies.

- Few discussions are made by the leaders at all administrative levels. Strategic planning requires discussions to identify its meaning, training in steps, and implementing stages.

This result matches the findings of Al-Shehri and Ibrahim (2018) that reported many organizational obstacles to strategic planning, such as the gap between the administrative levels in making and applying the strategic plan. It agrees with Machado et al. (2005), indicating that the most significant obstacles are ineffective use of the limited resources and the inability to motivate institutional innovation.

\subsection{Results of the Responses to the Items of the Second Domain}

Table 3. Frequencies, Arithmetic means, Standard Deviations, and Percentages of the Participants' Responses to the Items of the Second Domain "Defining Future Trends"

\begin{tabular}{|c|c|c|c|c|c|c|c|c|c|c|}
\hline \multirow[b]{2}{*}{ Items } & \multicolumn{5}{|c|}{ Response } & \multirow[b]{2}{*}{ Mean } & \multirow[b]{2}{*}{$\mathrm{SD}$} & \multirow{2}{*}{$\begin{array}{l}\text { Percentage } \\
\qquad(\%)\end{array}$} & \multirow[b]{2}{*}{ Level } & \multirow[b]{2}{*}{ Ranking } \\
\hline & $\begin{array}{l}\text { very } \\
\text { high }\end{array}$ & High & Moderate & Poor & $\begin{array}{l}\text { Very } \\
\text { poor }\end{array}$ & & & & & \\
\hline Define the future desired position & 20 & 28 & 9 & 5 & 1 & 3.97 & 0.97 & 79.37 & High & 3 \\
\hline Identify the fields of activities to formulate the vision & 24 & 30 & 7 & 2 & - & 4.21 & 0.77 & 84.13 & very high & 1 \\
\hline Draft and develop future vision & 22 & 26 & 10 & 5 & - & 4.03 & 0.92 & 80.63 & High & 2 \\
\hline $\begin{array}{l}\text { Define the required materials and resources to implement the } \\
\text { vision }\end{array}$ & 7 & 18 & 32 & 4 & 2 & 3.38 & 0.89 & 67.62 & Moderate & 5 \\
\hline $\begin{array}{l}\text { Identify partners (individuals or relevant entities) to achieve } \\
\text { the future vision }\end{array}$ & 8 & 10 & 28 & 16 & 1 & 3.13 & 0.99 & 62.54 & Moderate & 8 \\
\hline Draft the mission based on the available facilities & 13 & 28 & 17 & 1 & 4 & 3.71 & 1.02 & 74.29 & High & 4 \\
\hline $\begin{array}{l}\text { Turn the mission and achievement methods to long-term } \\
\text { straregic objectives }\end{array}$ & 4 & 23 & 32 & - & 4 & 3.37 & 0.87 & 67.30 & Moderate & 6 \\
\hline $\begin{array}{l}\text { Employ the efforts of academic departments to achieve } \\
\text { strategic objectives }\end{array}$ & 9 & 18 & 14 & 18 & 4 & 3.16 & 1.18 & 63.17 & Moderate & 7 \\
\hline Defining future trends & & & & & & 3.62 & & 72.38 & High & \\
\hline
\end{tabular}


Table (3) illustrates the responses to the items of the second domain concerning "future trends". Item (2) was rated high with a weighted average of (4.21) and a percentage of $(80.63 \%)$. This finding is obtained because the administration believes that defining the fields required for formulating vision is the beginning of achieving the vision to be authentic concerning the competitive, technological, economic, cultural, and social potential circumstances.

The responses to the items $(4,5,7$ and 8$)$ were rated moderate with weighted averages of (3.13-3.38) and percentages of $(62.54 \%-67.62 \%)$. This finding is due to:

- Lack of interest in training in the importance of the appropriate formulation of clear goals, harnessing expertise for strategic goals and choosing the appropriate means and methods.

- Weak development of appropriate methods and tools for providing the required data and information for strategic planning, continuous identification of the current situation, and evaluating the real situation based on historical development.

The responses to the items $(1,3$, and 6) were rated high with weighted averages of (3.71-4.0) and percentages of (74.29\%- 80.63\%). The second domain concerning "future trends" was rated high with a weighted average of (3.62) and a percentage of (72.38\%). This finding was obtained because:

- Leaders believe that the mission and vision shall be defined because they are important and fundamental for the faculty's success and continuous growth and survival.

- The administration is keen on formulating and spreading its message in a clear and accessible way. Thus, the future perspective (vision and mission) are available online and in brochures.

- Leaders are keen on the participation of scientific and administrative departments, as well as their commitment to develop the faculty and improve the quality of the educational process because they show an agreement among the staff on the future position.

- Leaders seek to introduce future orientation to the staff and stakeholders.

- The administration believes that the formulation of strategic objectives requires available individuals who can extrapolate the future. In addition, strategic objectives should be put into practice to be achieved, reviewed, and evaluated.

This result agrees with Dhaher (2016) that highlighted the administration's interest in strategic planning because of its role in promoting university work and developing education according to prepared plans. It also matches Sullivan and Richardson (2011) that asserted providing the leaders of educational institutions with a comprehensive model to support the initiatives of strategic planning.

\subsection{Results of the Responses to the Items of the Third Domain}

Table 4 shows the responses to the items of the third domain concerning "quadratic strategic analysis". Items $(2,4,5$, 7 , and 9) were rated moderate with weighted averages of (2.65-2.92) and percentages of $(53.02 \%-58.41 \%)$. This finding is obtained because:

- Listing opportunities and threats is necessary for defining the strategy and pathway to employ opportunities and keep threats away.

- Analyzing the external environment provides the administration with information to control and guide activities.

- The Faculty's administration is aware that environmental variables change rapidly. For example, an opportunity may be lost, and strength may turn into a weakness. Therefore, strengths shall be defined and promoted and weaknesses shall be defined and addressed to enhance the objectives and activities.

- The Faculty's administration believes that identifying and utilizing the strengths are necessary. Weaknesses shall be defined to address, overcome, or avoid them.

The responses to the items $(1,3,6$, and 8$)$ were rated low with weighted averages of (2.05-2.27) and percentages of (40.95\%-45.40\%). The responses of the participants to the third domain of "quadratic strategic analysis" were rated "low", with a weighted average of (2.50) and a percentage of (49.91\%). This result is due to the following reasons:

- Lack of a department for quadratic analysis.

- Lack of interest in training the faculty members in the skills of quadratic analysis and unavailability of its skills among them. 
- Weak facilities for the success of quadratic analysis, including the organizational structure and the appropriate selection of leaders.

- Inadequate strategic thinking because strategic planning requires awareness and knowledge of strategic thinking, as well as the alternatives and their potential.

- Lack of an accurate database to provide integrated information on the faculty's internal and external environments, such as identifying labor market needs and specializations and the wide gap between the outcomes of education and the labor market.

- Lack of integrated vision through the integrated internal view of the faculty (analysis of the internal environment) and a view of the outside world (analysis of the external environment).

This finding differs from Dhaher (2016) that concluded that strategic analysis takes place "very high" because of the interest of the senior administration of the university in continuous development based on the quadratic analysis.

Table 4. Frequencies, Arithmetic Means, Standard Deviations, and Percentages of the Participants' Responses to the Items of the Third Domain "Quadratic Strategic Analysis"

\begin{tabular}{|c|c|c|c|c|c|c|c|c|c|c|}
\hline \multirow[b]{2}{*}{ Items } & \multicolumn{5}{|c|}{ Response } & \multirow[b]{2}{*}{ Mean } & \multirow[b]{2}{*}{$\mathrm{SD}$} & \multirow[b]{2}{*}{$\begin{array}{l}\text { Percentage } \\
\qquad(\%)\end{array}$} & \multirow[b]{2}{*}{ Level } & \multirow[b]{2}{*}{ Ranking } \\
\hline & $\begin{array}{l}\text { very } \\
\text { high }\end{array}$ & High & Moderate & Poor & $\begin{array}{l}\text { Very } \\
\text { poor }\end{array}$ & & & & & \\
\hline $\begin{array}{l}\text { Form teamworks to do quadriatric strategic } \\
\text { analysis to forsee the future }\end{array}$ & 1 & 3 & 18 & 31 & 10 & 2.27 & 0.85 & 45.40 & Poor & 6 \\
\hline List potential opportunities and threats & 4 & 8 & 30 & 6 & 15 & 2.68 & 1.16 & 53.65 & Moderate & 3 \\
\hline Promote opportunities and avoid threats & 1 & 2 & 19 & 30 & 11 & 2.24 & 0.84 & 44.76 & Poor & 7 \\
\hline List and promote strengths & 2 & 9 & 39 & 8 & 5 & 2.92 & 0.85 & 58.41 & Moderate & 1 \\
\hline Define and handle weaknesses & 4 & 10 & 24 & 12 & 13 & 2.68 & 1.16 & 53.65 & Moderate & 3 Rep. \\
\hline $\begin{array}{l}\text { Link internal and external analyses to support } \\
\text { opportunities and avoid risks }\end{array}$ & & 3 & 10 & 37 & 13 & 2.05 & 0.75 & 40.95 & Poor & 9 \\
\hline Evaluate the human and material capabilities & 2 & 13 & 33 & 6 & 9 & 2.89 & 1.00 & 57.78 & Moderate & 2 \\
\hline $\begin{array}{l}\text { Analyze the efficiency of the faculty's } \\
\text { organizational structure based on quadrilateral } \\
\text { analysis }\end{array}$ & & 3 & 12 & 31 & 16 & 2.08 & 0.89 & 41.59 & Poor & 8 \\
\hline $\begin{array}{l}\text { Evaluate the strength of interpersonal } \\
\text { relationships and the integration of action groups } \\
\text { to ensure the success of strategic planning }\end{array}$ & & 18 & 10 & 14 & 17 & 2.65 & 1.32 & 53.02 & Moderate & 5 \\
\hline Quadratic strategic analysis & & & & & & 2.50 & & 49.91 & Poor & \\
\hline
\end{tabular}

\subsection{Results of the Responses to the Items of the Fourth Domain}

Table 5 illustrates the responses to the items of the fourth domain concerning "implementation of the strategic plan". Items (4 and 8) were rated moderate with weighted averages of (2.63-2.81) and percentages of $(52.70 \%-56.19 \%)$. However, the responses to the items $(1,2,3,6,7$, and 9) were rated low with weighted averages of (2.03-2.54) and percentages of (40.63\%-50.79\%). Item (5) was rated very poor with a weighted average of (1.60) and a percentage of $(32.06 \%)$.

The responses of the participants to the fourth domain of "implementation of the strategic plan" were rated "low", with a weighted average of (2.38) and a percentage of (45.61\%). This result is due to the following reasons:

- Limited facilities for the successful implementation of the strategic plan, including the organizational structure and the appropriate recruitment of leaders in the key positions of implementation.

- Weak administrative and financial support systems for the successful implementation of the strategy, as shown in the poor linking of the implementation of the strategic plan to the system of resource allocation and capital investment effectively.

- The weak practice of strategic leadership.

- Lack of adequate financial resources and skills to implement the plan.

- Lack of conviction of the participants in the benefits of implementing the strategic plan. 
- Unavailability of the appropriate database and information, evaluating the database of the Faculty of Education for strategic planning, and trust in the credibility of the information.

- Lack of interest in practical training in strategic planning and focusing on the academic aspect.

- Lack of conviction of the faculty members in the importance of developing a strategic plan, willingness to have teamwork, and a strong correlation between the faculty objectives and the benefits and advantages they receive.

- Change of the circumstances before and during the plan.

- Inadequate application of the sound scientific perspective concerning the participation of the staff in the development of the action plan, weak future performance, mistrust of the lower levels of practicing strategic planning, and desire to employ specialists and consultants.

This finding agrees with the results of Sart (2014) that highlight the misconception of the universities concerning the strategic plan. It matches the findings of Lillis and Lynch (2014) that illustrated significant deficits in terms of finance-related performance and the participation of the stakeholders.

Table 5. Frequencies, Arithmetic Means, Standard Deviations, and Percentages of the Participants' Responses to the Items of the Fourth Domain "Implementation of the Strategic Plan"

\begin{tabular}{|c|c|c|c|c|c|c|c|c|c|c|}
\hline \multirow[b]{2}{*}{ Items } & \multicolumn{5}{|c|}{ Response } & \multirow[b]{2}{*}{ Mean } & \multirow[b]{2}{*}{$\mathrm{SD}$} & \multirow{2}{*}{$\begin{array}{l}\text { Percentage } \\
\quad(\%)\end{array}$} & \multirow[b]{2}{*}{ Level } & \multirow[b]{2}{*}{ Ranking } \\
\hline & $\begin{array}{l}\text { very } \\
\text { high }\end{array}$ & High & Moderate & Poor & $\begin{array}{l}\text { Very } \\
\text { poor }\end{array}$ & & & & & \\
\hline $\begin{array}{l}\text { Implementing the strategic plan by turning the } \\
\text { strategy into actions }\end{array}$ & - & 1 & 16 & 33 & 13 & 2.08 & 0.73 & 41.59 & Poor & 6 \\
\hline $\begin{array}{l}\text { Developing the organizational structure that supports } \\
\text { the strategic plan }\end{array}$ & - & 8 & 16 & 26 & 13 & 2.30 & 0.94 & 46.03 & Poor & 5 \\
\hline $\begin{array}{l}\text { Allocating an adequate budget for the } \\
\text { implementation of the strategic plan }\end{array}$ & - & - & 36 & 22 & 5 & 2.49 & 0.64 & 49.84 & Poor & 4 \\
\hline $\begin{array}{l}\text { Allocating appropriate material and human resources } \\
\text { for the implementation of the strategic plan }\end{array}$ & 3 & 4 & 37 & 16 & 3 & 2.81 & 0.82 & 56.19 & Moderate & 1 \\
\hline $\begin{array}{l}\text { Adopting a system of rewards to motivate } \\
\text { departments to compete for improving the results }\end{array}$ & - & 2 & 2 & 28 & 31 & 1.60 & 0.71 & 32.06 & Very poor & 9 \\
\hline $\begin{array}{l}\text { Resolving all conflicts between occupational } \\
\text { activities to fit requirements of implementation }\end{array}$ & - & - & 15 & 35 & 13 & 2.03 & 0.67 & 40.63 & Poor & 7 \\
\hline $\begin{array}{l}\text { Establishing a control system to provide appropriate } \\
\text { feedback to implementation }\end{array}$ & - & 3 & 12 & 32 & 16 & 2.03 & 0.80 & 40.63 & Poor & 8 \\
\hline $\begin{array}{l}\text { Opening communication channels to facilitate } \\
\text { decision-making based on facts }\end{array}$ & 1 & 7 & 34 & 10 & 11 & 2.63 & 0.96 & 52.70 & Moderate & 2 \\
\hline $\begin{array}{l}\text { Developing measurable performance standards for } \\
\text { all items of the plan }\end{array}$ & 1 & 5 & 32 & 14 & 11 & 2.54 & 0.93 & 50.79 & Poor & 3 \\
\hline Implementation of the Strategic Plan & & & & & & 2.28 & & 45.61 & Poor & \\
\hline
\end{tabular}




\subsection{Results of the Responses to the Items of the Fifth Domain}

Table 6. Frequencies, Arithmetic Means, Standard Deviations, and Percentages of the Participants' Responses to the Items of the Fifth Domain "Evaluation and Strategic Oversight"

\begin{tabular}{|c|c|c|c|c|c|c|c|c|c|c|}
\hline \multirow[b]{2}{*}{ Items } & \multicolumn{5}{|c|}{ Response } & \multirow[b]{2}{*}{ Mean } & \multirow[b]{2}{*}{ SD } & \multirow{2}{*}{$\begin{array}{l}\text { Percentage } \\
\quad(\%)\end{array}$} & \multirow[b]{2}{*}{ Level } & \multirow[b]{2}{*}{ Ranking } \\
\hline & $\begin{array}{l}\text { very } \\
\text { high }\end{array}$ & High & $\begin{array}{c}\text { Mode } \\
\text { rate }\end{array}$ & Poor & $\begin{array}{l}\text { Very } \\
\text { poor }\end{array}$ & & & & & \\
\hline Comparing the results and the objectives of the strategic plan & 4 & 4 & 34 & 12 & 9 & 2.71 & 1.01 & 54.29 & Moderate & 1 \\
\hline $\begin{array}{l}\text { Setting indicators to evaluate the efficiency of achieving the } \\
\text { objectives }\end{array}$ & 1 & 4 & 10 & 39 & 9 & 2.19 & 0.82 & 43.81 & Poor & 5 \\
\hline Evaluating achievements against objectives & - & - & 26 & 32 & 5 & 2.33 & 0.62 & 46.67 & Poor & 2 \\
\hline $\begin{array}{l}\text { Concluding a final evaluation on the the failure or success of } \\
\text { the plan }\end{array}$ & - & 4 & 19 & 31 & 9 & 2.29 & 0.79 & 45.71 & Poor & 3 \\
\hline $\begin{array}{l}\text { Developing internal feedback evaluation indicating how the } \\
\text { strategy is implemented }\end{array}$ & - & 2 & 13 & 39 & 9 & 2.13 & 0.68 & 42.54 & Poor & 6 \\
\hline $\begin{array}{l}\text { Taking appropriate corrective actions through improvement } \\
\text { plans }\end{array}$ & 1 & 2 & 12 & 43 & 5 & 2.22 & 0.71 & 44.44 & Poor & 4 \\
\hline Evaluation and Strategic Oversight & & & & & & 2.31 & & 46.24 & Poor & \\
\hline
\end{tabular}

Table 6 shows the responses to the items of the fifth domain concerning "evaluation and strategic oversight". Item (1) was rated moderate with a weighted average of (2.71) and a percentage of (54.29\%). However, the responses to the items $(2,3,4,5$, and 6$)$ were rated low with weighted averages of (2.13-2.33) and percentages of $(42.54 \%-46.67 \%)$.

The responses of the participants to the fifth domain of "evaluation and strategic oversight", were rated "low", with a weighted average of (2.31) and a percentage of $(46.24 \%)$. This result is due to the following reasons:

- Poorly-developed clear performance indicators.

- Lack of interest in formulating a group of experts to carry out periodic evaluations.

- Lack of interest in publishing the results of follow-up and evaluation and reviewing strengths, weaknesses, opportunities, and threats.

- Lack of interest in preparing a team to evaluate the strategic plan due to the inadequate skills of evaluation and strategic control of the faculty members.

- Lack of interest in the development and ineffectiveness of training programs for the parties in charge of evaluating the strategic plan.

This result agrees with Aldajney (2006) that the university does not apply clear performance standards and indicators to evaluate the plan adequately. It matches the findings of Gordon and Fischer (2015) that concluded the lack of systemic infrastructure established by the university to monitor the actual and planned results to define corrective actions.

\section{Conclusion}

The results show the weak practice of the leaders of the Faculty of Education, Damietta University of strategic planning. The second domain was ranked first and rated "high" with a weighted average of (3.62) and a percentage of $(72.38 \%)$, while the first domain was ranked second and rated "moderate" with a weighted average of (3.14) and a percentage of $(62.74 \%)$. The $3^{\text {rd }}, 4^{\text {th }}$, and $5^{\text {th }}$ domains concerning "quadratic strategic analysis, implementation of the strategic plan, and evaluation and strategic oversight" were rated low. Their weighted averages were rated (2.28$2.50)$ with a percentage of (49.91\%-64.24\%), as shown in figure 1. 


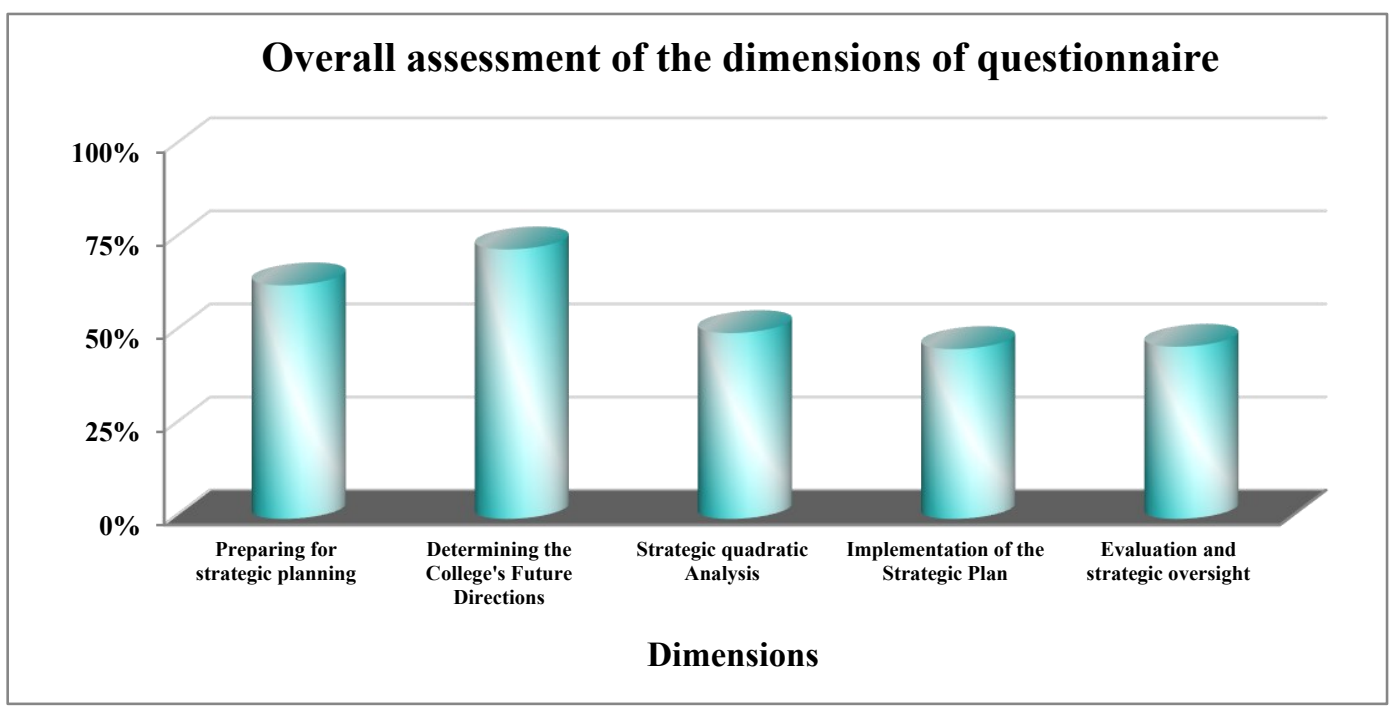

Figure 1. Percentage of the Participants' Responses to the Overall Evaluation of the Domains of the Questionnaire

This finding is due to the following reasons:

- Internal resistance: The staff members are reluctant to the introduction of the strategic planning system.

- The high cost of planning: Conducting studies and research requires time and effort.

- Current crises: Strategic planning is a tool to avoid future problems and crises and not to overcome an emergent crisis. Therefore, the time spent on strategic planning can be dedicated to handle short-term and emergent problems.

- Difficult planning requires a high level of imagination, analytical ability, innovation, choosing, different mental processes, and management talents, and development of the leaders, faculty members and staff need in terms of making and implementing plans.

- Dedicating time to short-term problems and routine work.

- Unavailability of the motivating atmosphere of strategic planning, such as experienced leaders in planning and information and communication systems to develop integrated information on the internal and external environments.

- Lack of interest in defining the administrative and technical skills and abilities and participation of the faculty members in the development of the planning mechanism and strategic planning.

- Inefficient methods and tools of analysis, discussion, and processing of data and utilizing them in the preparation and update of the strategic plan.

- Failure to prioritize strategic planning because of its inadequate time compared to other administrative processes.

- The inadequate response, discussion, and interaction with the suggestions and perceptions of the faculty to evaluate the workflow and achieve the objectives of the Faculty.

- The faculty members' lack of interest in attending meetings and workshops on the effective participation, implementation, and evaluation of strategic planning, raising awareness of the correct implementation of the strategic plan, as well as prompt objective response to changes in the development and update of the plan.

- Inadequate time for strategic management because of the tendency to centralization and routine work.

- The focus of the system of incentives on short-term results instead of the long-term strategic objectives.

- Prevalence of the bureaucratic organization and leadership.

- Centralization of some senior leaders and insufficient delegation of authorities to the concerned staff.

\section{Recommendations}

- Develop strategic thinking for both the faculty members and university leaders on the short and long terms through professional development programs. 
- Develop a mechanism of consolidating the culture of strategic planning and making it a part of the general culture of the Faculty of Education.

- Develop a database for the purposes of strategic planning.

- Establish a special unit at the Faculty for strategic planning tasks.

- Train the faculty members and leaders in the skills of strategic planning.

\section{References}

Aldajney, E. (2006). The reality of strategic planning at the Islamic University in the light of quality standards (MA. thesis). Faculty of Education, Islamic University of Gaza.

Al-Shehri, E., \& Ibrahim, M. (2018). Organizational obstacles to applying strategic planning in the emerging Saudi universities: A case study on Prince Sattam bin Abdulaziz University. Journal of Research in Education, 19(1), $1-37$.

Badrakhan, S. (2016). The reality of strategic planning at the public and private Jordanian universities based on total quality standards. Proceedings of the Sixth Arab International Conference of the Assurance of Higher Education Quality (pp.266-283). Sudan: Sudan University of Science and technology.

Chang, G. (2006). Strategic planning in education: Some concepts and steps. France: UNESCO.

Dahawy, B., \& Almelegy, R. (2011). Strategic planning in education. Cairo: Dar Alfikr Alaraby.

Damietta University (2014/2015). Self study report of Damietta University. Available from http://www.du.edu.eg/upFilesCenter/uni/1453207878.pdf.

Dhaher, R. (2016). Strategic planning practice and relationship to e-learning development at the Palestinian universities (Al-Quds Open University- a case study) (MA. thesis). Faculty of Education, Islamic University of Gaza.

Faculty of Education. (2008). Strategic plan of the Faculty of Education in Damietta in the light of quality assurance and continuing improvement (2008-2012). Retrieved from http://www.du.edu.eg/upFilesCenter/uni/1453207878.pdf

Gomaa, E. (2012). Strategic planning in university education: Concepts, aims, and operations. Journal of the Faculty of Education in Suez, 5(5), 262-293.

Gordon, G., \& Fischer, M. (2015). Strategic planning in public higher education: Management tool or publicity platform? Educational Planning, 22(3), 5-17.

Han, S., \& Zhong, Z. (2015). Strategy maps in university management: A comparative study. Educational Management Administration \& Leadership, 43(6), 939-953. https://doi.org/10.1177/1741143214552860

Hassanien, M. (2017). Strategic planning in higher education, a need for innovative model. Journal of Education, Society and Behavioural Science, 23(2), 1-11. https://doi.org/10.9734/JESBS/2017/37428

Lillis, D., \& Lynch, M. (2014). New challenges for strategy development in Irish higher education institutions. Higher Education Policy, 27(2), 279-300. https://doi.org/10.1057/hep.2013.23

Machado, M., Taylor, J., Farhangmehr, M., \& Wilkinson, R. (2005). Strategic planning in Portuguese higher education institutions. Planning for Higher Education, 34(1), 29-39.

Michael, F., \& Liz, W. (2009). Strategic planning in colleges and universities. Business Renaissance Quarterly, 4(1), 91-103.

Obeidat, T. (2011). The role of strategic planning in developing the higher education sector and state its directions and future policies. Proceedings of the Regional Seminar on the Establishment of a Network of Strategic Planning Experts in the Fields of Higher Education. Muslim World Union, IESCO, Yarmouk University and Jordan University of Science and Technology-Irbid, Jordan.

Orians, E., \& Bergerson, A. (2014). Lessons learned: Mountain College in the midst of change. Journal of Cases in Educational Leadership, 17(3), 59-69. https://doi.org/10.1177/1555458914543374

Sart, G. (2014). Strategic model and strategic planning in higher education. International Journal of Social and Economic Sciences, 4(1), 34-37. 
Sullivan, T., \& Richardson, E. (2011). Living the plan: Strategic planning aligned with practice and assessment. Journal of Continuing Higher Education, 59(1), 2-9. https://doi.org/10.1080/07377363.2011.544975

Tess, H. (2018). Effective strategic planning in Australian universities: How good are we and how do we know? Journal of Higher Education Policy and Management, 40(5), 442-457. https://doi.org/10.1080/1360080X.2018.1501635 